SCR -15

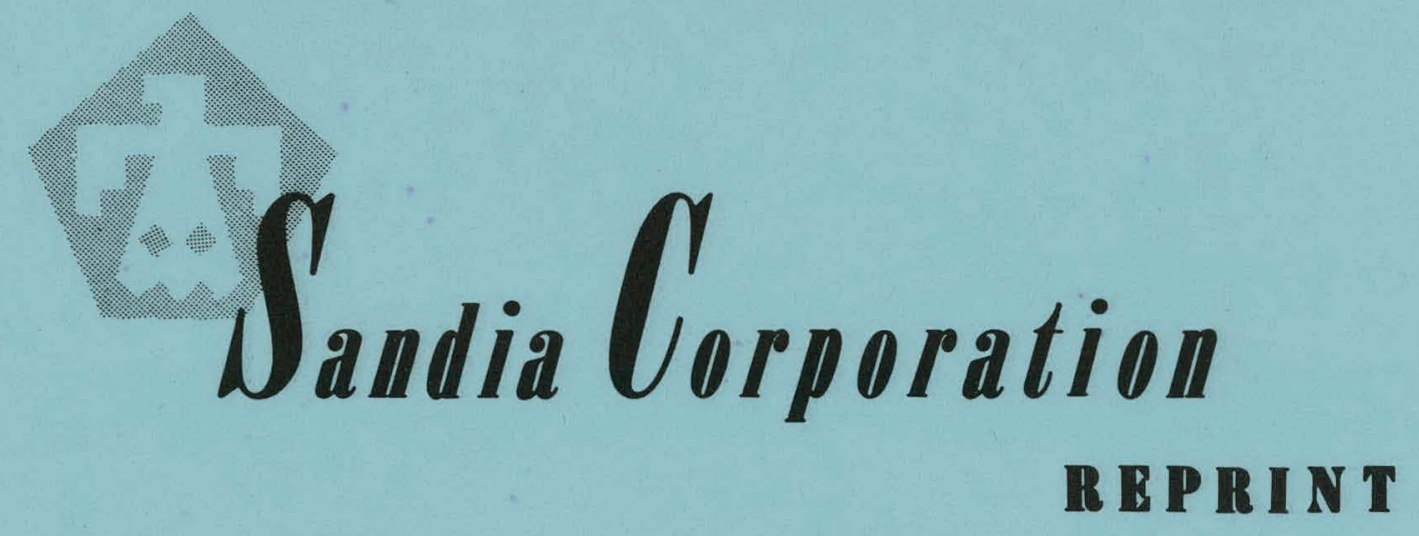

A FACILITY FOR THE STUDY OF
THE EFFECTS OF NUCLEAR
RADIATION ON MATERIALS

by

J. L. COLP

and

A. W. SNYDER

JUNE, 1958

WORK PERFORMED UNDER AEC CONTRACT AT-(29-1)-789 


\section{DISCLAIMER}

This report was prepared as an account of work sponsored by an agency of the United States Government. Neither the United States Government nor any agency Thereof, nor any of their employees, makes any warranty, express or implied, or assumes any legal liability or responsibility for the accuracy, completeness, or usefulness of any information, apparatus, product, or process disclosed, or represents that its use would not infringe privately owned rights. Reference herein to any specific commercial product, process, or service by trade name, trademark, manufacturer, or otherwise does not necessarily constitute or imply its endorsement, recommendation, or favoring by the United States Government or any agency thereof. The views and opinions of authors expressed herein do not necessarily state or reflect those of the United States Government or any agency thereof. 


\section{DISCLAIMER}

Portions of this document may be illegible in electronic image products. Images are produced from the best available original document. 
Presented at Sixty-First Annual Meeting

AMERICAN SOCIETY FOR TESTING MATERIALS

Boston, Massachusetts. June 22-27, 1958

LEGAL NOTICE

This report was prepared as an account of Government sponsored work. Neither the United States, nor the Commission, nor any person acting on behalf of the Commission:

A. Makes any warranty or representation, express or implied, with respect to the accuracy, completeness, or usefulness of the information contained in this report, or that the use of any information, apparatus, method, or process disclosed in this report may not infringe privately owned rights; or

B. Assumes any liabilities with respect to the use of, or for damages resulting from the use of any information, apparatus, method, or process disclosed in this report.

As used in the above, "person acting on behalf of the Commission" includes any employee or contractor of the Commission to the extent that such employee or contractor prepares, handles or distributes, or provides access to, any information pursuant to his employment or contract with the Commission.

Reactors - General (TID-4500 13th Edition Rev. 2)

Price 75 cents. Available from the Office of

Technical Services, Department of Commerce, Washington 25, D. C. 


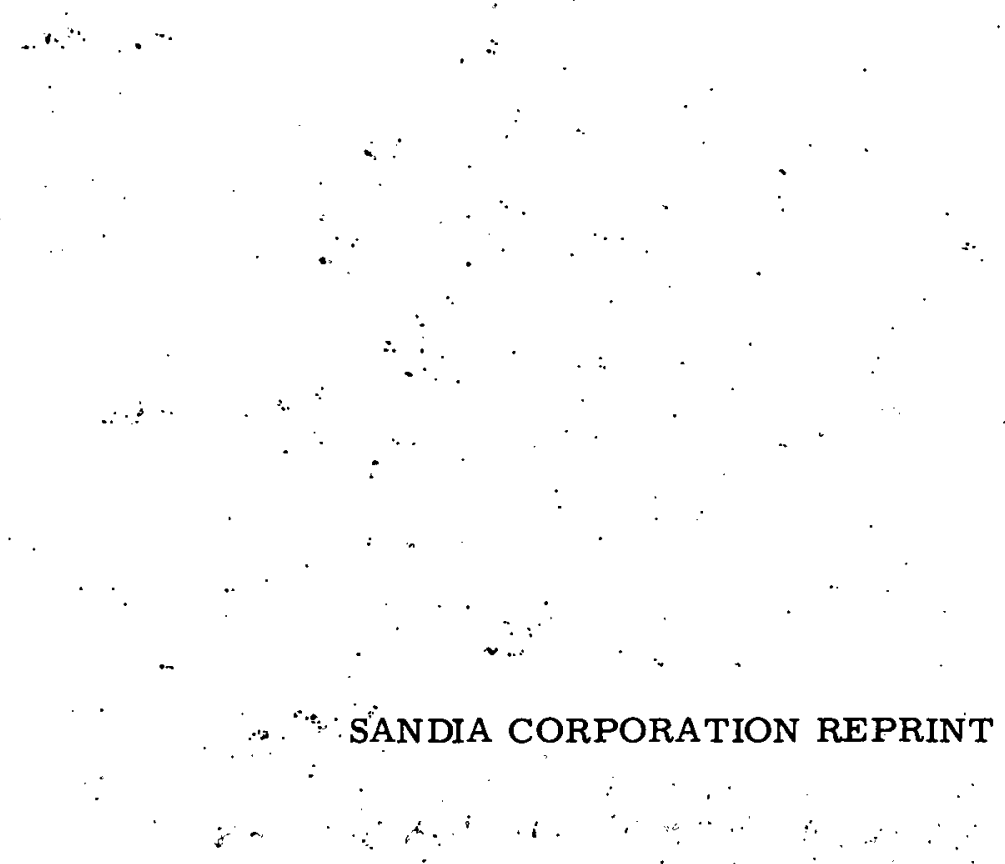

A FACILITY FOR THE STUDY OF THE EFFECTS OF NUCLEAR RADIATION ON MATERIALS

by

John L. Colp and A. William Snyder

JUNE 1958

Work performed under AEC Contract AT-(29-1)-789 
Presented at Sixty-First Annual Meeting

AMERICAN SOCIETY FOR TESTING MATERIALS

Boston, Massachusetts. June 22-27, 1958

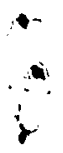




\title{
A FACILITY FOR THE STUDY OF THE EFFECTS OF NUCLEAR RADIATION ON MATERIALS
}

4

\author{
ABSTRACT
}

The Sandia Engineering Reactor Facility consists of a 5-megawatt light water moderated heterogeneous-type nuclear reactor, a large dry irradiation room and the necessary laboratory space for the preparation and post-irradiation testing of material samples. This Facility will be used to study the effects of radiation on the engineering properties of materials. Equipment for producing additional environments of heat, cold, altitude and vibration will be available for compounding with the radiation environment during material tests.

An interesting feature of the operating concept for this facility is the plan to operate the reactor on a continuous, 24-hour per day, seven-day per week basis except for required reactor shut downs. This feature means that provisions must be made in the design of the facility to provide for the remote insertion and removal of test objects during full power reactor operation. Accordingly, an interesting arrangement of radiation cell entrance locks and a remotely operated electric tug system has been designed. An inexpensive method for providing instrumentation leads from the test being irradiated to the instrument room has been designed.

A special feature of this facility is the proposed concept for performing post-irradiation testing and analysis. Instead of having several heavily shielded individual "hot cells", this facility has one large "hot a rea". This "hot area" is separated from the remainder of the Facility by a 42 -inch-thick concrete shielding wall containing six high-density lead glass windows, each equipped with a pair of Argonne Model 8 manipulators. Materials for postirradiation testing and analysis are brought to each window by means of a specially designed Mobile Remote Handler. This Handler is a mobile, electrically driven vehicle containing one man. This man inside this vehicle is shielded by approximately $6-1 / 2$ inches of lead. The vehicle is equipped with one General Mills mechanical arm operated by the man inside the $\mathrm{cab}$ and viewed by him through a high-density lead glass window. This concept of a large "hot room" results in considerable savings in facility costs over the normal individual "hot cell" type of construction. 


\section{A FACILITY FOR THE STUDY OF THE EFFECTS OF NUCLEAR RADIATION ON MATERIALS}

The Sandia Engineering Reactor Facility--which we call the SERF--is an engineering tool for use in the study of the engineering properties of materials which represents an integrated approach to the problem of radiation effects. The center of the facility is a nuclear reactor especially designed to optimize leakage of fast neutrons. Also included are laboratories and shops for preparation of material specimens before irradiation, as well as extensive areas and laboratories for post-irradiation analysis. Laboratories for the development and application of material dosimetry methods and office space complete the facility.

First to be considered, because it is the very heart of the facility, is the Sandia Engineering Reactor (SER) that produces the nuclear radiation environment. The reactor is of a standard--if such a word can be used in a field as new as that of nuclear reactors--lightly pressurized tank type. It has a heat power rating of 5,000 kilowatts and is cooled, moderated, and reflected by light water. The core, or active region, of the reactor is inside a stainless steel pressure vessel which extends into and passes through the irradiation cell. The core is in the center of that portion of the pressure vessel which passes through the cell.

The pressure vessel is seen in vertical cross section in Slide 1 . The vessel diameter, which is eight feet at its largest section, narrows by several transitions into a diameter of. 30 inches at the core section. Cooling water entering the water inlet shown is diverted upwards and around the periphery of the pressure vessel. The water flows down through the pressure vessel, past the core, and then returns to the outside heat exchanger through the outlet pipe shown at the bottom of the slide. Also shown on top of the pressure vessel are the control-rod drives that actuate the control rods, one of which is shown in section, to permit accurate and safe control of the reactor.

With Slide 2 we proceed to a cross section through the core, the active region of the reactor. The SER is what is known as a heterogeneous-type reactor; that is, uranium fuel in metallic form is placed inside fuel rod assemblies and is cooled by water which does not come into direct contact with it. The fuel rod used is a standard MTR type consisting of a series of plates containing uranium-aluminum fuel alloy. The plates are covered with pure aluminum. on all outside surfaces and are assembled into a complete fuel rod. As can be seen in the section view, 32 fuel rods are used in a full loading of the core. There are approximately 3 inches of cooling water between the core assembly and the inside surface of the pressure vessel. This small amount of water was chosen to provide an adequate amount of reflector, while still permitting maximum leakage of neutrons from the core. The pressure vessel at this section is made of aluminum with a cylindrical sheet of boral, a material made of aluminum and boron carbide, just inside the aluminum to decrease the number of thermal (low-energy) neutrons escaping from the core region.

Not much need be said of either the control and safety system or the cooling system; both being rather conventional in design. The control system is built up of ordinary electronic components and utilizes a servo system for automatic control of the power level of the reactor during operation. The cooling system is of stainless-steel piping throughout. Pumps, surge tank, demineralizer, filters, and heat exchanger are located in a separate building about 85 feet from the reactor proper, so that the cooling system need not be extensively shielded. 
Perhaps the best way to present the Sandia Engineering Reactor Facility fully and completely is to describe in sequence the operations required to perform a typical test, pausing where appropriate to point out novel features of the system. Slide 3 shows the completely underground operational floor of the SERF. A sample to be irradiated is brought down the ramp from the outside into the preparation area for preirradiation checking and instrumentation tests. It is placed on a specially built four-wheel trailer, and any required instrumentation leads are connected to it.

After preirradiation preparations have been completed, the trailer containing the sample is moved into radiation lock No. 1, access to which is through a heavy concrete shielding door which lowers into a well below the floor. This door cannot be opened unless the doors between radiation lock No. 1 and the irradiation cell are in the "up" or closed position. The trailer is placed on a pair of tracks in the lock, after which personnel leave and the shielding door between the lock and cold preparation area is closed.

One of the novel features of the SERF is that samples can be inserted and removed from the irradiation cell without shutting down the reactor. Because material samples can be brought into the radiation cell without interrupting other tests, a large number of tests can progress simultaneously even though they may not be of the same duration. This obviously represents great convenience and efficiency of operation. By properly utilizing this feature, we expect to be able to make a great many radiation effects tests in a minimum time.

Samples are inserted by remote control into the irradiation cell while the reactor is in operation in the following way. The doors between radiation lock No, 1 on the right, radiation lock No. 2 on the left, and the irradiation cell in the center are simultaneously lowered. An electrically driven, remotely operated tug is then moved along the pair of tracks on which the trailer containing the material sample has been placed. It automatically couples with the trailer and draws it into the irradiation cell to a predetermined position. Then it automatically decouples and is withdrawn into radiation lock No.2. Finally, the doors between the locks and the irradiation cell are closed.

Slide 4 is an artist's drawing of the remotely operated tug and a typical trailer. The tug is a four-wheeled vehicle driven by a three-horsepower electric motor. It is powered and controlled through a trailing cable from a power reel located in radiation lock No. 2. The motor is protected from the radiation in the irradiation cell by a few inches of lead and several inches of borated water.

To return to the irradiation procedure. After the sample has been irradiated, the shielding door between radiation lock No. 2 and the irradiation cell, shown in Slide 5 , is lowered into the open position. The remotely operated tug again enters the irradiation cell, remotely couples with the trailer, and withdraws it and the irradiated sample into radiation lock No. 2, after which the shield doors are raised. Next the shlelding door between luck No. 2 and the hot area shown on the left of the floor plan is lowered to permit access from the hot area. Although the radiation level in lock No. 2 produced by the operating reactor itself is low enough at this time to permit the entrance of human beings, the trailer and sample are so radioactive that an unprotected human cannot approach them. Accordingly, special means had to be provided to remove the test sample from the radiation lock to the hul ared fur pusl-irradiation test. ing. Such moving is done with a heavily shielded, tracked vehicle called a Mobile Remote Handler, use of which is another interesting innovation in the facility.

An artist's drawing of this vehicle is seen in Slide 6. The Mobile Remote Handler was conceived by Sandia Corporation and designed under contract by the Mechanical Division of General Mills, Inc. The vehicle is built on a caterpillar tractor type of chassis. To protect the operator from the lethal radiations of the activated sample, the cab on the front is made of lead, 6.5 inches thick. The operator, looking out through a 12 -inch-thick leaded-glass window, can perform certain gross manipulations with the General Mills Mechanical Arm which is mounted on the front of the vehicle. A 30-horsepower-drive motor, a bank of storage batteries, 
and other accessories are mounted on the rear of the handler. Because of the large leadshielded $\mathrm{cab}$, the vehicle is expected to weigh about 85,000 pounds.

The Mobile Remote Handler is driven into radiation lock No. 2, shown in Slide 7, where it safely removes the irradiated material sample, takes it into the hot. area, and places it in front of any one of six manipulator positions. These manipulator positions consist of leadedglass shielding windows placed in a 42 -inch-thick concrete shielding wall. Above each window is a pair of Central Research Laboratory Model 8 Master-Slave Manipulators. A man on the cold side of the wall can use the manipulators to work on the radioactive samples with perfect safety.

After the desired post-irradiation tests, the radioactive material samples are carried by the Mobile Remote Handler into the hot storage area shown in the lower left hand corner of Slide 7 to be stored until radioactivity decays. Later they are completely decontaminated and disposed of.

The large hot area which has just been described is another unique feature of the SERF. Most irradiation facilities employ a series of individual hot cells for post-irradiation tests. In the SERF, these hot cells have been replaced by the large hot area, a change which results in several advantages. Among these are a considerable saving in initial construction costs, maximum flexibility in post-irradiation testing, and a decrease in the decontamination of hot areas required. This new design would not have been possible without the conception and development of the Mobile Remote Handler. Because such a hot area would contain many radioactive objects, unprotected human beings simply could not have entered it. However, the Mobile Remote Handler enables men to enter the area, move about it at will, and perform gross manipulations. The entire hot area is also covered by a pair of remotely operated bridge cranes which provide an additional handling capability.

Sandia, continuing to study remote handling, has recently developed a Robot Mobile Remote Handler, an artist's drawing of which is shown in Slide 8. This handler is completely controlled from behind a shielding wall by means of power and information transmitted through a trailing cable. It is equipped with two television cameras and one modified General Mills Mechanical Arm, so that gross manipulations may be remotely performed. This robot version of the handler is intended to supplement the capability offered by the manned handler. Since shielding is not required, it is considerably lighter and cheaper than the manned vehicle.

Post-irradiation facilities are provided by laboratories in the cold area shown in Slide 9. The laboratory at the center of the slide contains a small pool of water which is used for inserting samples through a rabbit tube system directly into the reactor core. A series of four pipes leads from the pool to the core. Small shuttles containing samples for irradiation can be inserted in the tube and hydraulically driven into the core. After irradiation, the shuttles are withdrawn into the pool and removed. Although this facility is restricted to rather small samples, it is very valuable because samples are placed very close to the core and its high fluxes.

The ground floor of the facility is shown in Slide 10. Here are located offices, some electronics laboratories, and a counting room. The reactor control room and the operating floor of the reactor can be seen on the lower portion of the slide. This area is directly above the irradiation cell, which is separated from the control area by a concrete shield 8.5 feet thick to prevent harmful radiation from penetrating to the upper working area. In several places, the concrete shield is pierced by serpentine ducts to permit instrumentation cables from the sample in the radiation cell to be connected to test instrumentation in the control area. In this manner, data from samples being irradiated can be recorded.

One other capability should be mentioned, namely, that the SERF also provides for testting materials in compounded environments. A material sample can be simultaneously tested in an environment of radiation combined with other environments of heat, cold, vibration, and 
altitude. This is done by placing the sample inside the specially built environmental chamber shown in Slide 11. This chamber is connected through ducts in the floor of the irradiation cell to an equipment room outside the reactor building which contains equipment necessary to generate the environment desired. The environment chosen is then blown through the ducts into the environmental chamber. (Also shown in this figure are the previously mentioned instrumentation ducts which lead to the operating floor above the irradiation cell. )

In conclusion, we feel that the SERF constitutes a thoroughly practical approach to the problem of determining the effects of radiation on the engineering properties of materials. Through the use of this facility, we expect to learn a great deal about radiation effects and how they can be taken into account in engineering designs. The final design work of the facility is now underway, and construction should be finished and the reactor started in September 1959. 
a

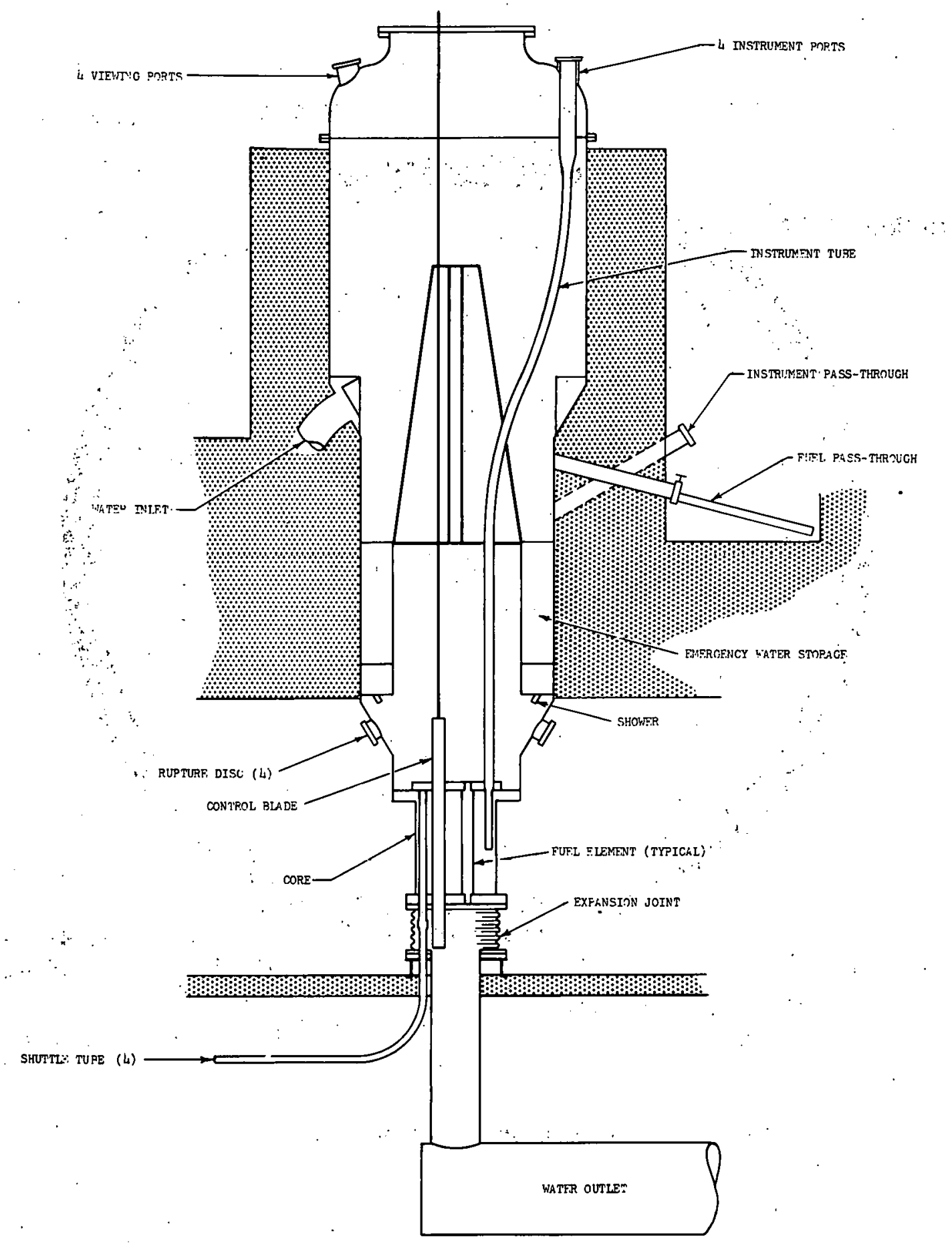

Slide 1 -- Vertical section through reactor core and pressure vessel 


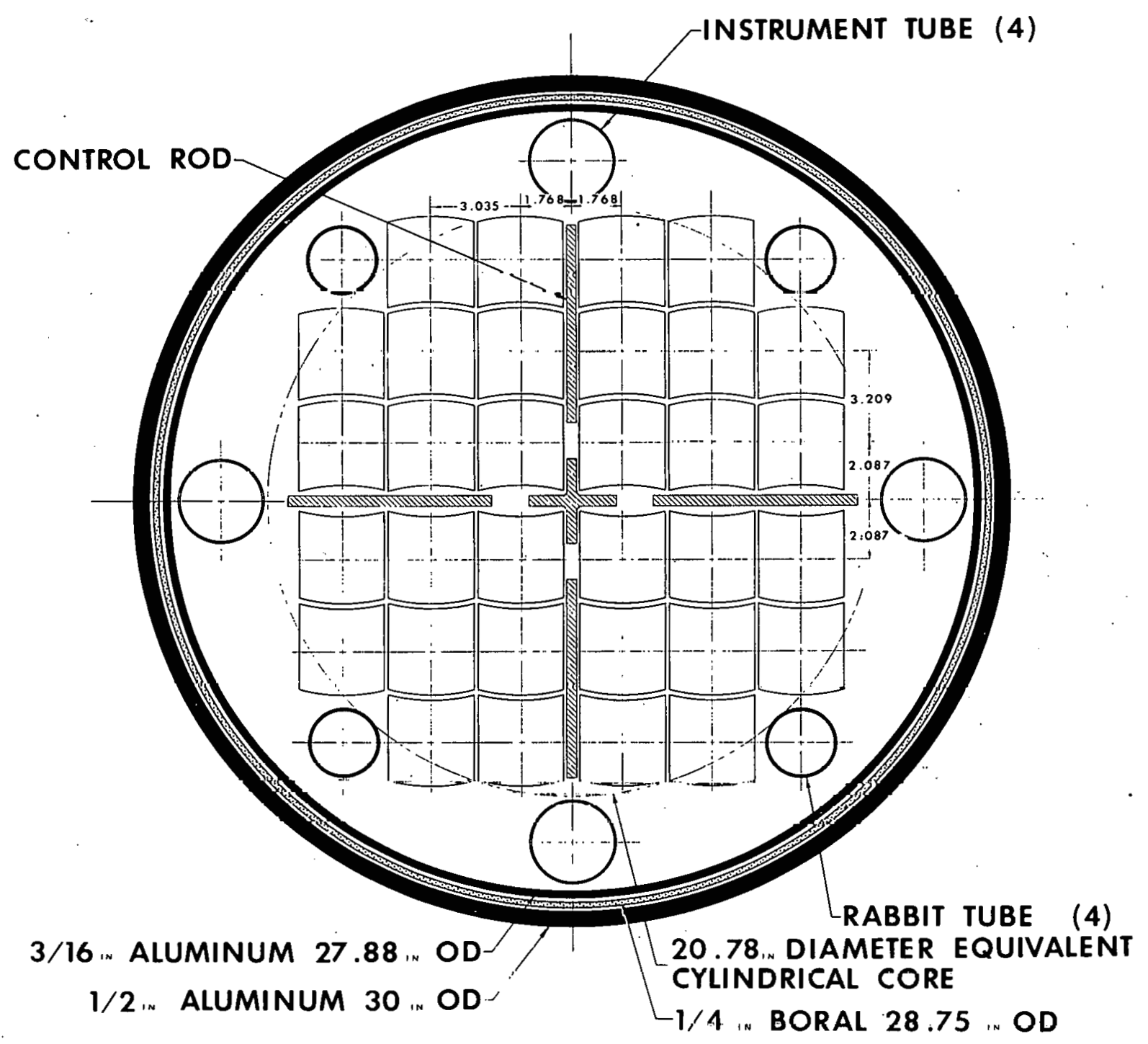

Slide 2 -- Horizontal section through reactor core 


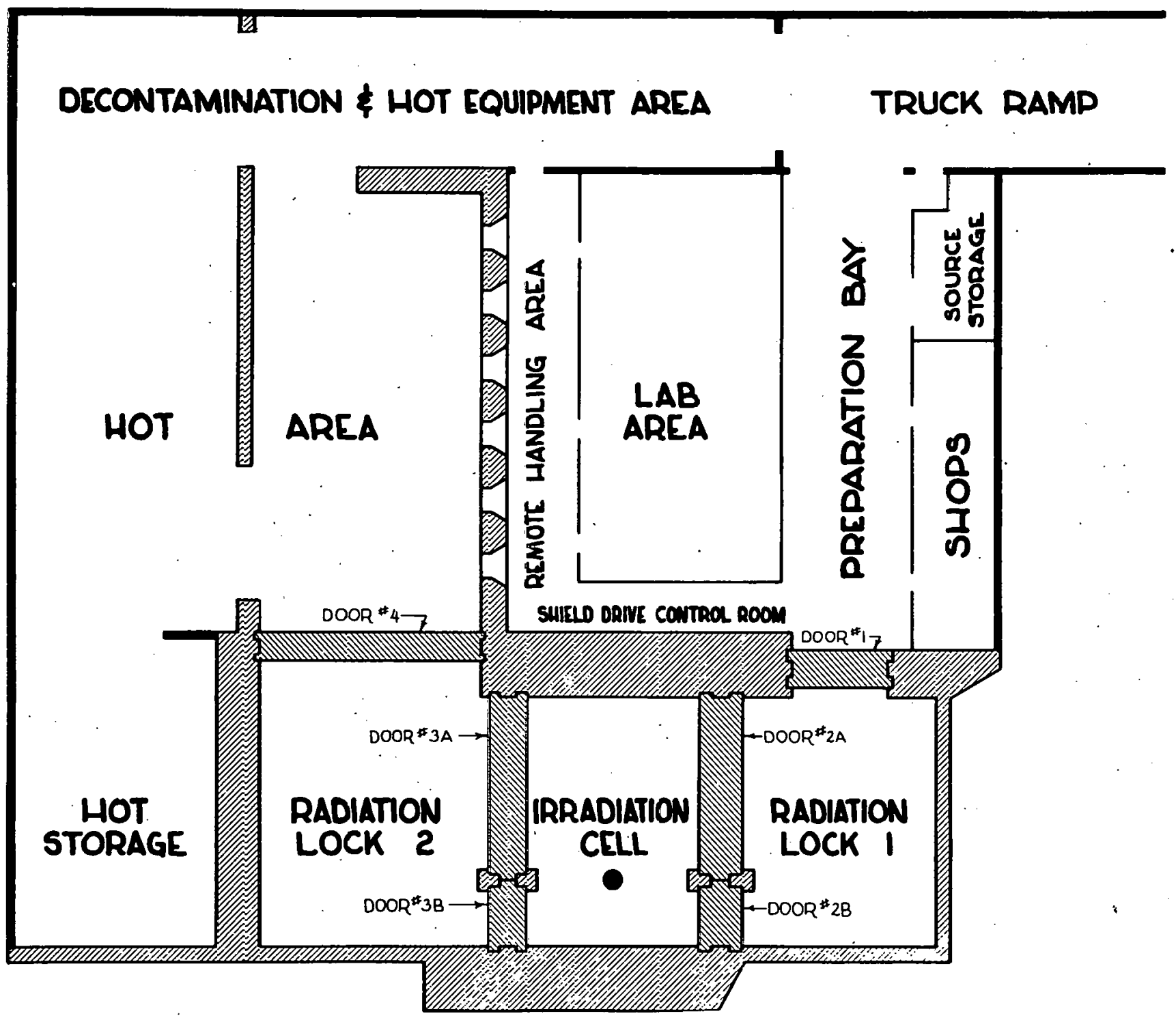

Slide 3 - - Basement floor plan 


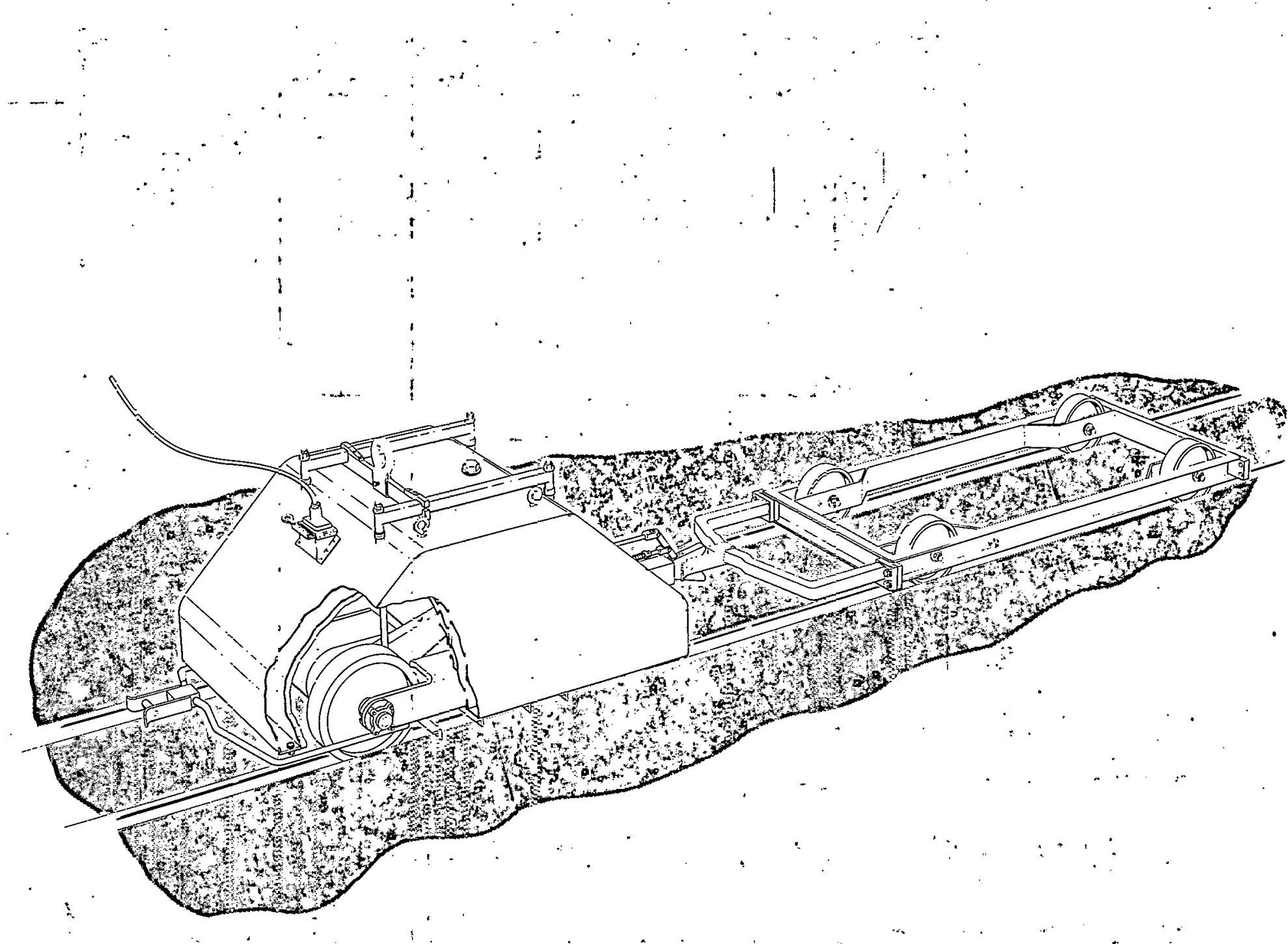

Slide 4 -- Remoteìy operated tug and trailer. 


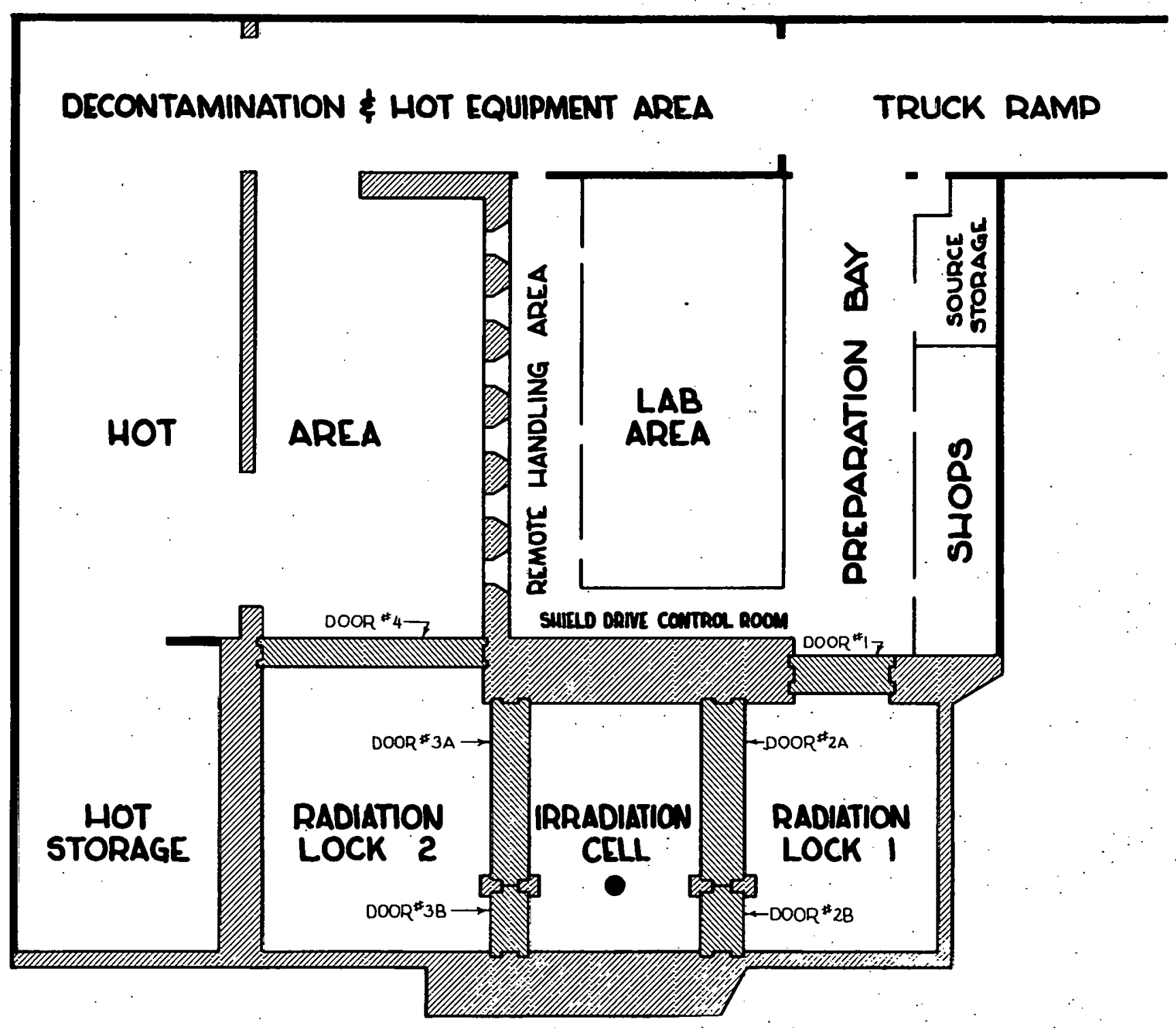

Slide 5 - - Basement floor plan 


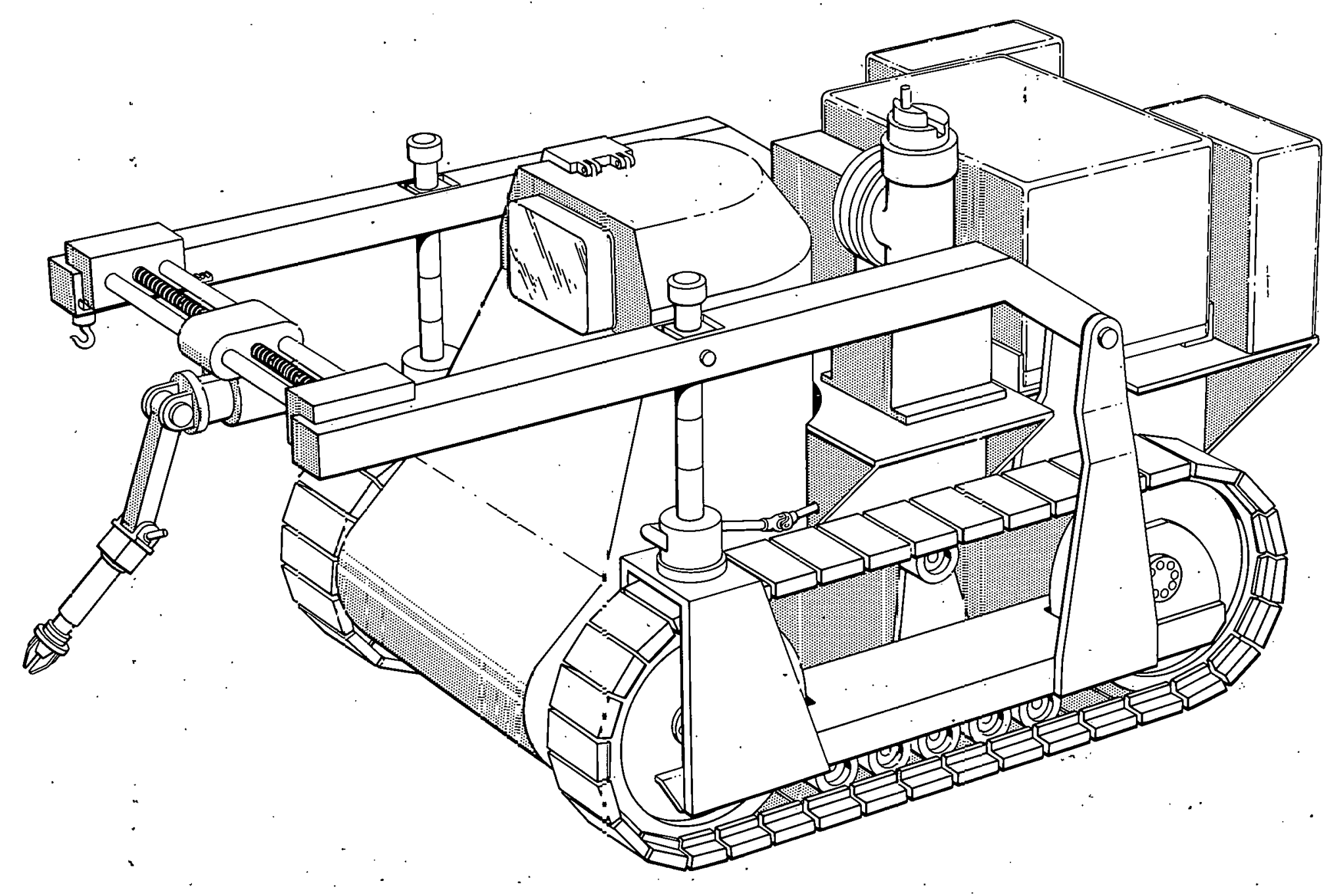

Slide 6 - - LIobile remote handler 


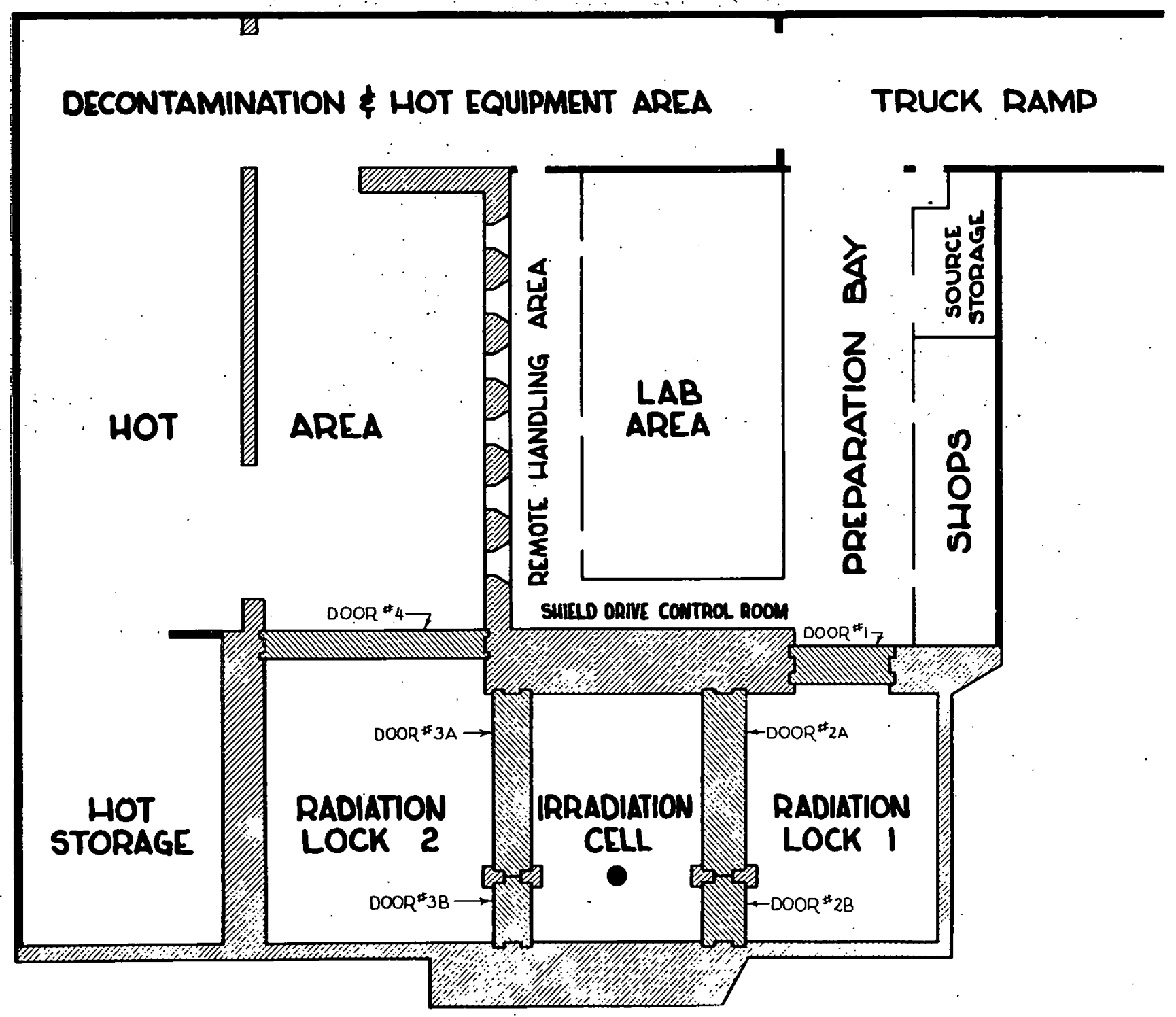

Slide 7 - Basement floor plan 


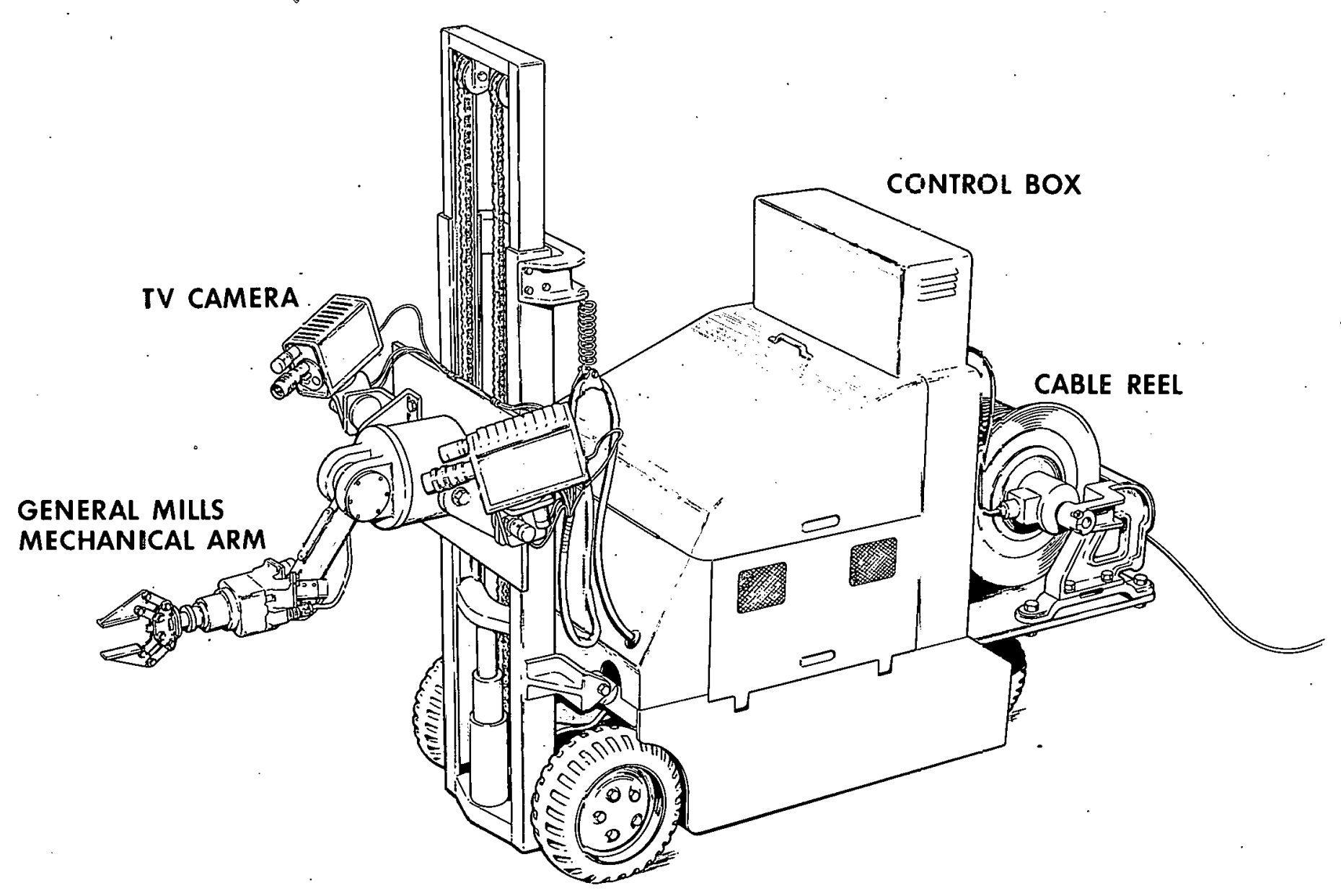

Slide 8 -- Sandia rcbot mobile remote handler 


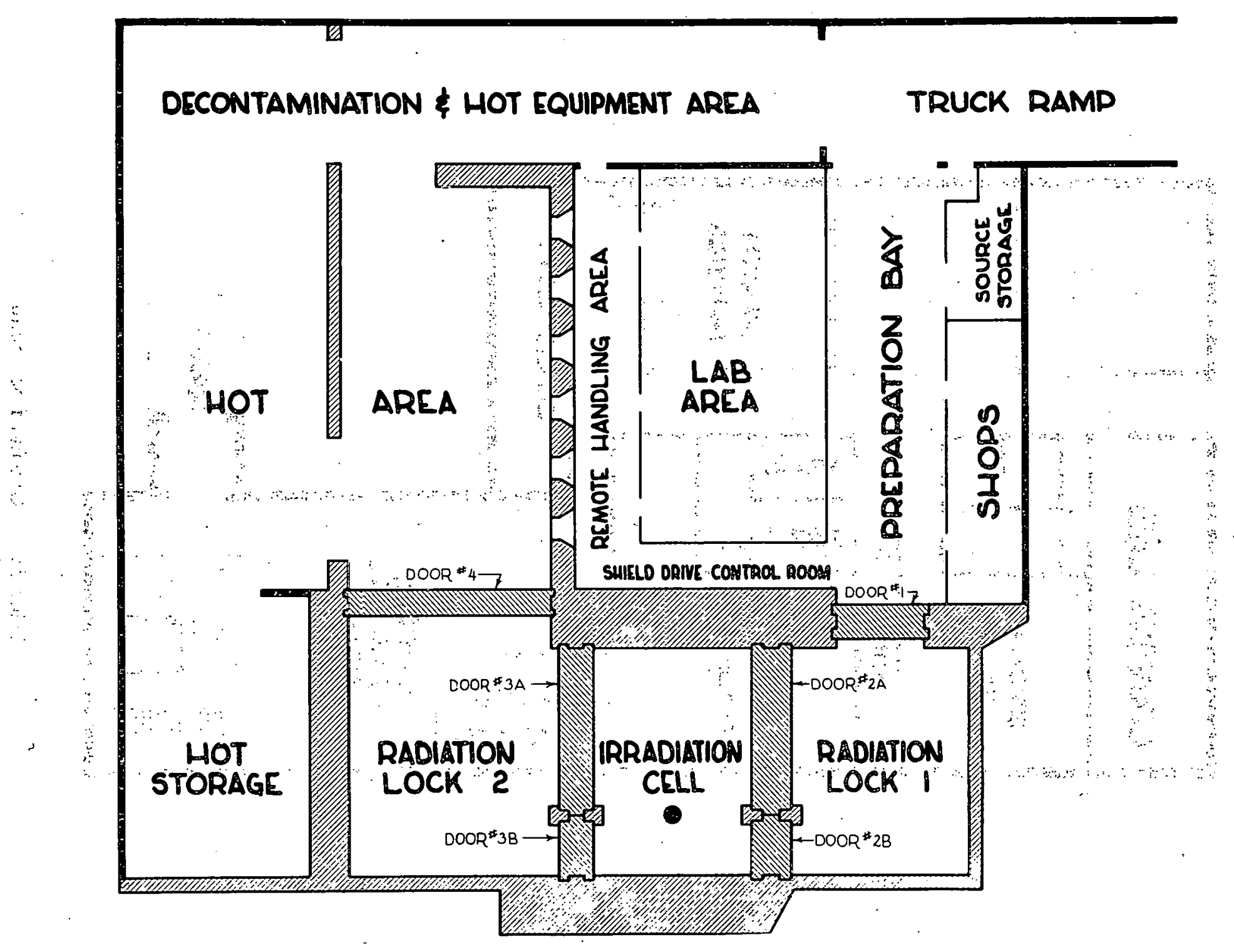

Slide 9 -- Basement floor plan 


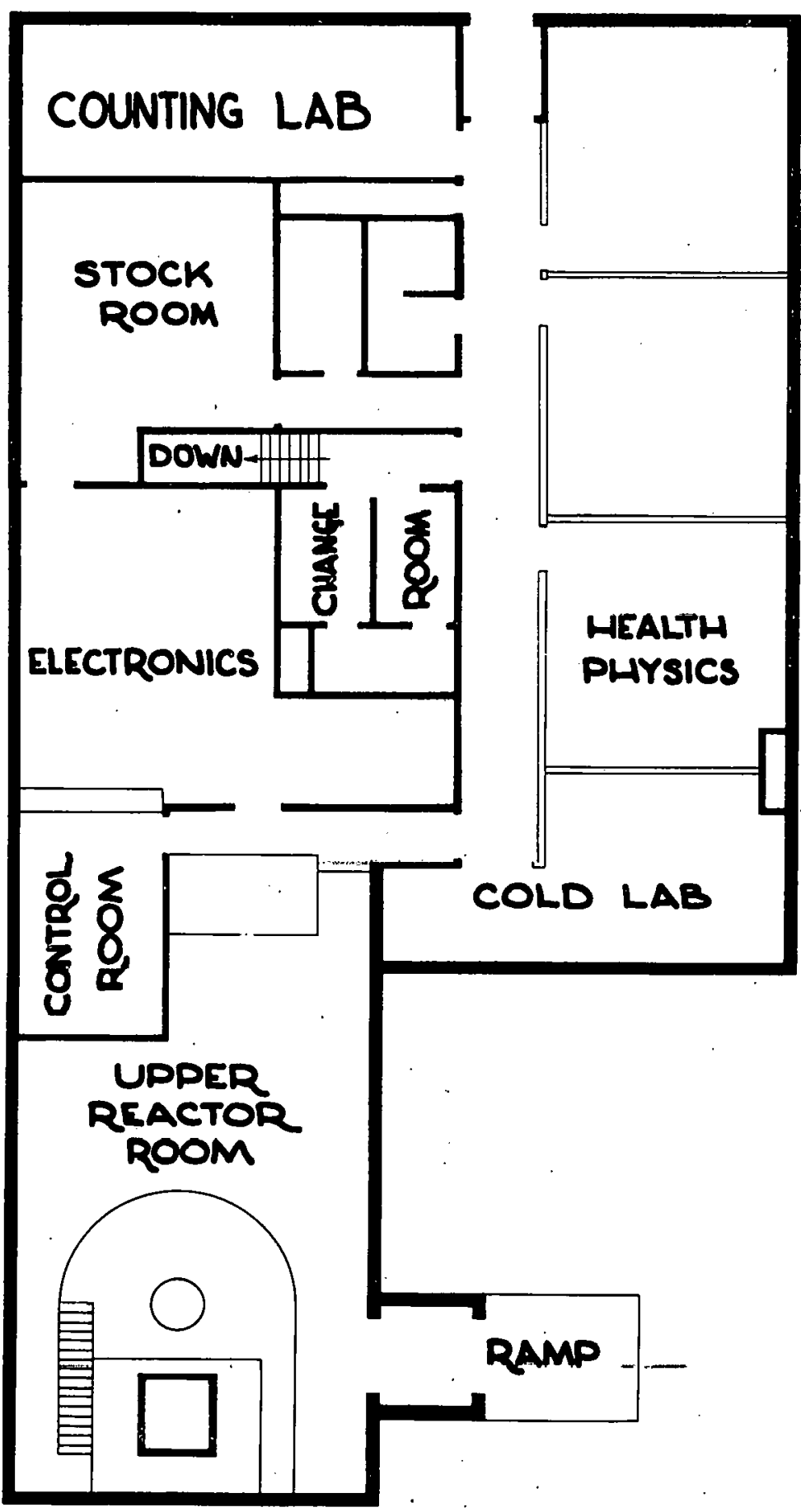

Slide 10 -- Ground floor plan 


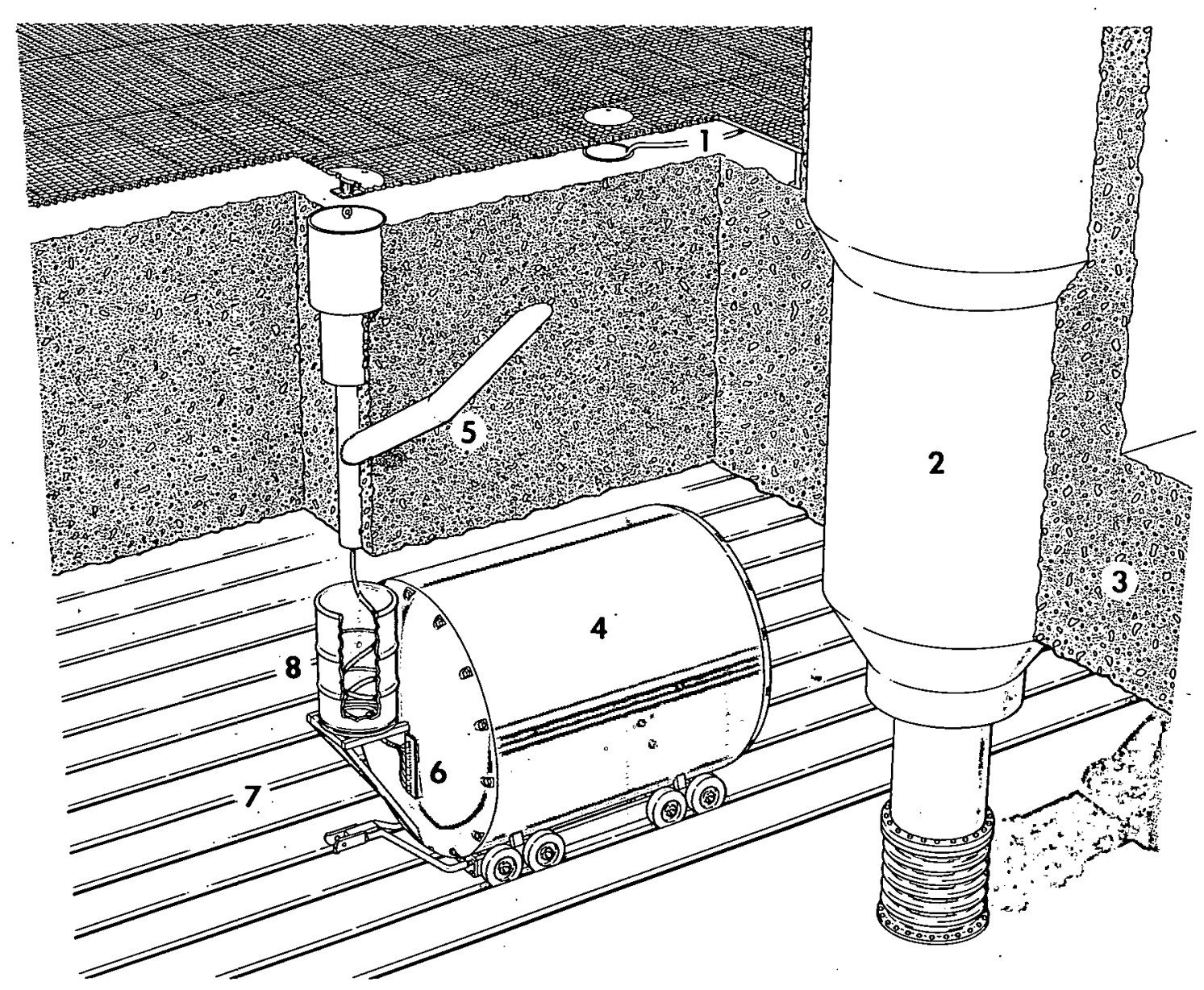

1 TO INSTRUMENTATION

2 5MW REACTOR

3 UPPER SHIELD (CONCRETE)

4 TEST CHAMBER
5 TEST INSTRUMENTATION CABLE DUCT

6 TERMINAL STRIP

. 7 TRACKS (CHANNEL)

8 CABLE DRUM 
REACTORS - GENERAL

(TID 4500 13th Edition, Rev. 2)

No. of Copies

3

1

1

1

10

1

1

2

3

4

Aberdeen Proving Ground

AEC Scientific Representative, Argentina

AEC Scientific Representative, France

AEC Scientific Representative, Japan

Alco Products, Inc.

Argonne National Laboratory

Armed Forces Special Weapon Project, Washington

Armed Services Technical Information Agency

Army Ballistic Missile Agency

Army Chemical Center

Atomic Energy Commission, Washington

Atomics International

Babcock \& Wilcox Company

Battelle Memorial Institute

Bettis Plant

Boeing Airplane Company

Brookhaven National Laboratory

Brush Beryllium Company

Bureau of Medicine and Surgery

Bureau of Ships (Code 1500)

Canel Operations

Chicago Operations Office

Chicago Patent Group

Combustion Engineering, Inc.

Consolidated Vultee Aircraft Corporation

Convair-General Dynamics

Curtiss -Wright Corporation

Defence Research Member:

Department of Food Technology (MIT)

Department of Navy (Code 422)

Department of the Army, G-2

Division of Raw Materials, Denver

Dow Chemical Company (Rocky Flats)

Du Pont de Nemours and Company, Aiken

Du Pont de Nemours and Company, Wilmington

Evans Signal Laboratory

Frankford Arsenal

General Electric Company (ANPD)

General Electric Company, Richland

General Nuclear Engineering Corporation

Iowa State College

Jet Propulsion Laboratory

Kirtland Air Force Base

Knolls Atomic Power Laboratory

Lockheed Aircraft Corporation (Bauer)

Los Alamos Scientific Laboratory

Mallinckrodt Chemical Works

Maritime Administration

Massachusetts Institute of Technology (Dr. Hardy)

Mound Laboratory

National Advisory Committee for Aeronautics, Cleveland 
REACTORS - GENERAL

(TID 4500 13th Edition, Rev. 2) Continued

No. of Copies

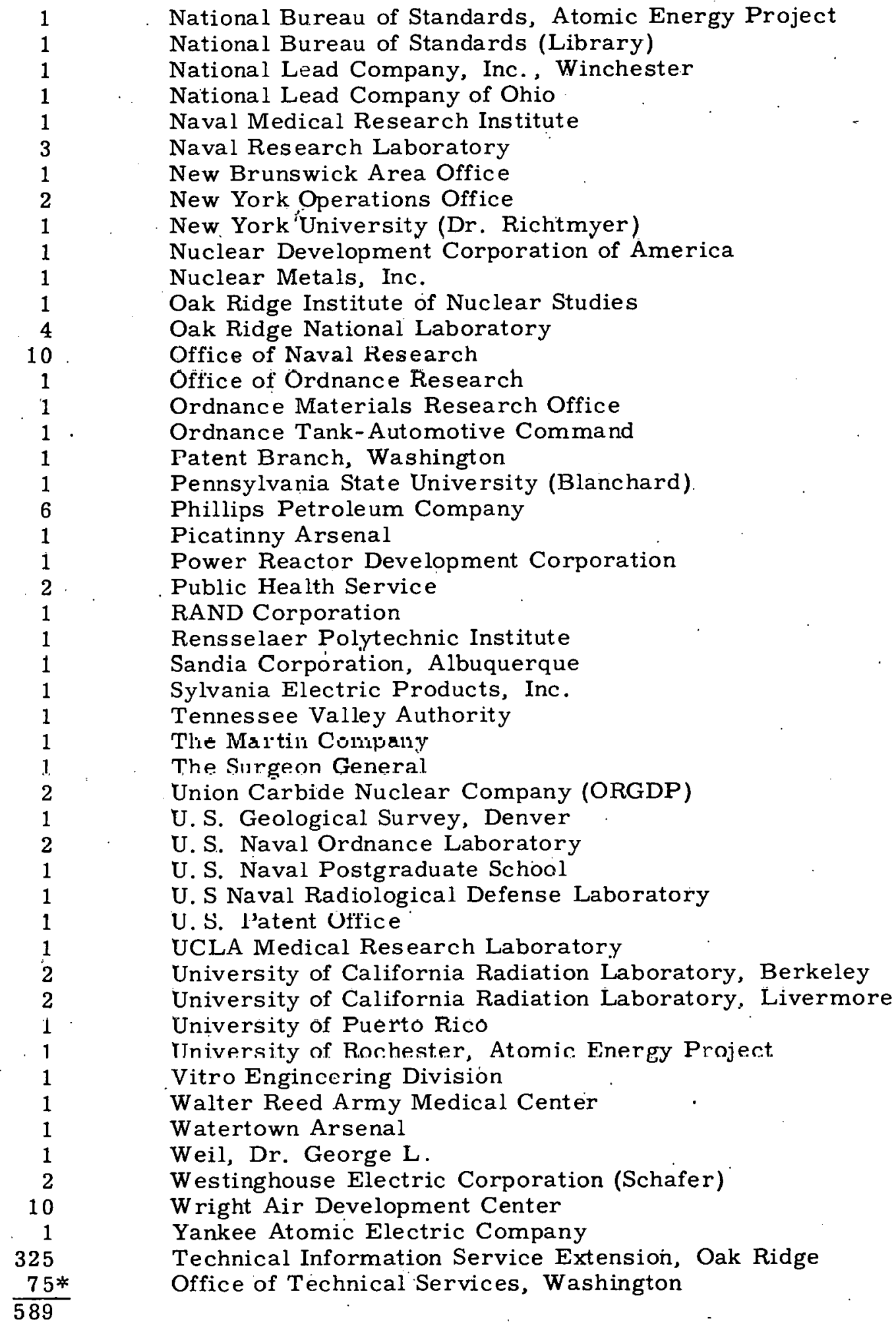

* These copies should be shipped directly to the Office of Technical Services, Department of Commerce, Washington 25, D. C. 
Issued By

Technicāi Information Division

Sandia Corporation

Albuquerque, New Mexico 